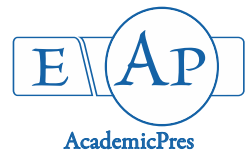

\title{
Purification, Characterization and Antioxidant Potential of a Novel Lectin from Pterocarpus soyauxii Taub Seeds
}

\author{
Oludele Olayemi ODEKANYIN*, Atinuke Shakirat KAYODE, \\ Joseph Olufemi ADEWUYI \\ Obafemi Awolowo University, Ile-Ife, Biochemistry and Molecular Biology Department, \\ Nigeria; dekanyin@oauife.edu.ng ( ${ }^{*}$ correspondingauthor); kayodesakirat92@gmail.com;fadewuyi819@gmail.com
}

\begin{abstract}
The study investigated the presence of lectin in the seeds of Pterocarpus soyauxii, purified the lectin and determined its physicochemical properties as well as its antioxidant potential. Purification of P. soyauxii seeds lectin (PSSL) was accomplished by ammonium sulphate precipitation and gel filtration on Sephadex G-100, hemagglutination assay was by serial dilution and DPPH radical scavenging, metal chelating and lipid peroxidation inhibition assays were employed to evaluate its antioxidant potential. PSSL agglutinated erythrocytes from human blood group ABO, rabbit and rat. Trypsinization enhanced agglutination which was inhibited by galactose, lactose and arabinose. The lectin activity was independent of metal ion, thermal stable up to $60^{\circ} \mathrm{C}$ and at $\mathrm{pH}$ range of 6 to 8 . Gel filtration estimated molecular weight was $65 \mathrm{kDa}$ and subunit molecular weight was $35 \mathrm{kDa}$. PSSL showed significant antioxidant activity. The lectin was able to scavenge DPPH radical, chelate iron metal and inhibit lipid peroxidation with $\mathrm{IC}_{50}$ of $0.14 \pm 1.33 \mathrm{mg} / \mathrm{ml}, 3.40 \pm 0.37 \mathrm{mg} / \mathrm{ml}$ and $0.50 \pm 0.08 \mathrm{mg} / \mathrm{ml}$ respectively. The results indicate that PSSL might be applied as natural antioxidant for the development of drug and food products for the benefit of human health.
\end{abstract}

Keywords: antioxidant; hemagglutination; lectin; Pterocarpus soyauxii; seed

\section{Introduction}

Globally research towards the development of drug from natural sources for various ailments that is ravaging the world is increasing. Many plants have been examined for their pharmacological, nutraceutical and therapeutic potentials and different bioactive agents have also been isolated from them. Among biologically active agents is lectin, which is a protein or glycoprotein. It has the ability to bind reversibly and specifically to carbohydrate on the surface of the cells thereby precipitating or agglutinating them (Lam and Ng, 2011). Lectins are well distributed in nature, found in animals, plants and microorganism (Sharon and Lis, 2004; Hamid et al., 2013). Lectins have been found to be valuable tools in scientific research especially in the area of biocontroling, bone marrow transplantation, cancer diagnosis, HIV/AIDS and others (Inbar and Chet, 1997; Bouwman et al., 2006; Lam and Ng, 2011; Huskens and Schols, 2012; Yau et al., 2015). In addition, lectins have been shown to possess various biological activities like anticoagulant, antitumor, antibacterial, antiproliferative, anti-inflammatory, analgesic, insecticidal and antiviral (Singh et al., 1999; Lam and Ng, 2011; Kumar et al., 2012; Hamid et al., 2013; Santos et al., 2014; Dan et al., 2016; Lagarda-Diaz et al., 2017; Hendrickson and Zherdev, 2018). They are considered strong candidates for therapeutic usage because they are macromolecules with noticeable resistance to adverse conditions like $\mathrm{pH}$, temperature variations and isotonicity, with no major changes to their biological functions (Coffey et al., 1993). Also, the characteristic property of lectins to recognise other molecules in a distinct way makes it relevant in various research and applications (Santos et al., 2014).

Recently, lectin research received a boost when it was reported to have the ability to scavenge free radicals (Pan and Ng, 2015; e Lacerda et al., 2017; Olodude et al, 2017) which provided them the potential to protect the human body against damage caused by free radicals and reactive oxygen species released during oxidative stress. The development of several chronic diseases such as cancer, aging, arthritis, cardiovascular diseases, diabetes and neurodegenerative disorder is linked to oxidative stress (Anitha and Sathisha, 2017). Treatment of these disorders needs supply of external antioxidant to improve the internal

Received: 31 May 2018. Received in revised form: 06 Dec 2018. Accepted: 20 Mar 2019. Published online: 21 Mar 2019. 
defence system which may be overwhelmed by the excessive exposure to oxidative stress (Anitha and Sathisha, 2017). Therefore, there is need for development of more natural antioxidant from potential food sources which can reduce or thwart oxidative stress and its harmful effects. This possibly may replace the synthetic antioxidants which are high-priced and have adverse side effects.

Among the plant family which had their lectins well investigated for various biological properties is Leguminosae. Legume seeds have been the major focus of lectin-related research. Leguminous lectins are the most studied group of lectins and hundreds of these proteins have been isolated and extensively investigated in relation to their chemical, physicochemical, structural and biological properties (Sun et al., 2011). The studies of leguminous lectins are focused mainly on the subfamily Papilionoideae but yet some tribes of this family are rarely investigated. Few lectins from Dalbergieae tribe have been isolated, characterized and includes Lonchocarpus capassa (Joubert $e t$ al., 1986), Vatairea macrocarpa (Calvate et al., 1998), Pterocarpus angolensis (Echemendia-Blanco et al., 2009), Platypodium elegans (Benevides et al., 2012), Platymiscium floribundum (Pereira-Junior et al., 2012), Vatairea guianensis (Silva et al., 2012a), Centrolobium tomentosum (Almeida et al., 2016), and Centrolobium microchate (de Vasconcelos et al., 2015). Pterocarpus soyauxii is a species of Pterocarpus genus belonging to the Dalbergieae tribe and family Leguminosae. It is native to central and tropical West Africa countries like Nigeria, Congo-Kinshasa and Angola. The common English name is African padauk/coralwood while it is called Osun pupa by the Yoruba tribe of Western Nigeria. The leaves are edible and contain large amounts of vitamin $\mathrm{C}$; the fresh leaves are used as vegetables and as livestock feed for goats, they are also recommended for consistent use for diabetics (Uzodimma, 2013). They are used in herbal medicine to treat skin parasites and fungal infections (Gill, 1992). The leaves have also been reported to be capable of normalising the hematological abnormalities associated with pathophysiology of diabetes mellitus (Saliu et al., 2012). The ethanolic leaf extract of Pterocarpus soyauxii has been reported to have antimicrobial activity. At high concentration, it significantly inhibited the growth of Escherichia coli, Salmonella typhi, Shigella flexneri, Staphylococcus aureus, Klebsiella pneumoniae and Candida albicans (Osuagwu and Akomas, 2013). Tchamadeu et al. (2011) reported that the aqueous stem bark extract of Pterocarpus soyauxii had very low toxicity in oral acute high dose administration and no toxicity in oral sub-chronic low dose administration in mice and thus concluded that the plant could be considered safe for oral medication. With enormous information available on the usage of this plant for the possible treatment of various disorders, no information is available at the time of complying this report on the health benefit of the seeds of Pterocarpus soyauxii.

The present study was therefore designed to isolate protein with hemagglutinating activity from Pterocarpus soyauxii seeds, purify the lectin, determine its physicochemical properties and evaluate the antioxidant potential of the purified lectin.

\section{Materials and Methods}

\section{Collection and identification of seeds}

The fruits of Pterocarpus soyauxii were collected from the Botanical Garden, Department of Botany, Obafemi Awolowo University, Ile-Ife, Nigeria. The plant and fruit were identified at IFE Herbarium in the same department.

\section{Preparation of the crude extracts of P. soyauxii seeds}

Pterocarpus soyauxii seeds were removed from the fruits and air-dried. The seeds were dehulled and milled. The milled samples were defatted with petroleum ether and gentle stirring. The defatting process was further repeated for complete removal of the oily constituents. The defatted samples were homogenized in $25 \mathrm{mM}$ phosphate buffered saline (PBS, pH 7.2) containing $100 \mathrm{mM} \mathrm{NaCl}$. The mixtures were stirred overnight using a magnetic stirrer. The homogenates were centrifuged at $10000 \mathrm{rpm}$ for 20 minutes using cold centrifuge and the collected supernatant termed crude lectin extract was frozen and stored.

\section{Glutaraldehyde fixation of erythrocytes}

Human blood groups A, B, O was obtained from healthy donors after informed consent. Rabbit and rat erythrocytes were obtained from healthy rabbit and rat purchased from Teaching and Research Farm, Obafemi Awolowo University, Ile Ife.

The animal and human red blood cells (RBC) were fixed with glutaraldehyde according to the method of Pattanapanyasat et al. (2010). Blood samples were collected into heparinized bottles and centrifuged at $3000 \mathrm{rpm}$ for 15 $\mathrm{min}$. The erythrocytes were collected and washed five times with PBS, pH 7.2. A $50 \%$ glutaraldehyde was diluted to $1 \%$ (v/v) with PBS and chilled at $4{ }^{\circ} \mathrm{C}$. The chilled glutaraldehyde-PBS solution was used to dilute the red blood cells to $2 \%(\mathrm{v} / \mathrm{v})$. The suspension of cells and glutaraldehyde was incubated for $1 \mathrm{~h}$ at $4^{\circ} \mathrm{C}$ with occasional mixing. The fixed cells were collected by centrifugation at $3000 \mathrm{rpm}$ for $5 \mathrm{~min}$ and washed five times with PBS. The cells were then suspended in PBS, containing $0.02 \%(\mathrm{w} / \mathrm{v})$ sodium azide, to a final concentration of $2 \%(\mathrm{v} / \mathrm{v})$ and stored at $4^{\circ} \mathrm{C}$ until further use.

\section{Trypsinization of red blood cells}

Trypsinization was carried out using the method of Occena et al. (2007). Blood samples of blood groups A, B and $\mathrm{O}$ were collected in heparinized bottles and centrifuged at $3000 \mathrm{rpm}$ for $15 \mathrm{~min}$. The erythrocytes were collected and washed three times with PBS and 2\% suspension was prepared in PBS for each of the blood groups. For trypsinization process, $1 \%$ trypsin was mixed with $2 \%$ red blood cells suspension in PBS in a ratio of $1: 1(\mathrm{v} / \mathrm{v})$ and was incubated at $37^{\circ} \mathrm{C}$ for $1 \mathrm{~h}$. After incubation, the trypsinized cells were washed with PBS three times, diluted and resuspended in PBS (2\% v/v), and stored until further use.

\section{Hemagglutination assay}

The crude lectin extract of $P$. soyauxii seeds was tested for the presence of lectin by hemagglutination assay performed by the method of Odekanyin and Kuku (2014). 
114

Hemagglutination assay was carried out in 96-well Ushaped microtiter plates. PBS $(100 \mu \mathrm{l})$ was delivered sequentially into wells arranged in rows of 12 wells. The crude extract $(100 \mu \mathrm{l})$ was added into the first well to obtain a 1:2 dilutions. A serial dilution was then performed by transferring $100 \mu \mathrm{l}$ of the diluted sample in a particular well into the next well containing $100 \mu \mathrm{l}$ PBS. This process was carried out for two complete rows of 12 wells each until the last $24^{\text {th }}$ well. Aliquots $(50 \mu \mathrm{l})$ of the $2 \%$ glutaraldehydetreated erythrocytes suspension of the animal and human blood samples were added separately to each well and the wells were left for $2 \mathrm{~h}$ for agglutination to take place. The hemagglutination titre of the lectin is defined as reciprocal of the highest dilution of the extract exhibiting visible hemagglutination - this will be equivalent of one hemagglutination unit (HU). Blood group specificities of the lectins were determined as described above with different blood groups.

Sugar specificity test

The sugar specificities of the lectins were investigated by comparing sugars on the basis of minimum concentration required to inhibit the agglutination of erythrocyte by lectins as described by Kuku and Eretan, (2004). This was done in two steps. In the first step, lectin was successively diluted until the end-point dilution causing hemagglutination was obtained. $0.2 \mathrm{M}$ of sugar solution was added to each well at $50 \mu \mathrm{l}$ per well, while the control well contained PBS instead of sugar solution. Fifty microlitres of erythrocyte suspension was added to each well, and the hemagglutination titre of the lectin was determined. Inhibitory sugars caused a reduction in the titre of the lectin activity shown by PBS-control experiment. The sugars tested are: maltose, D-(+)-mannose, lactose, L-(+)arabinose, sorbose, $\mathrm{D}-(+)$-glucose, galactose, mannitol, $\mathrm{N}$ acetyl-D-glucosamine, mannosamine, 2-deoxy-D-glucose, dulcitol, xylose, methyl $\alpha$-D--glucopyranoside and D-(+)glucosamine $\mathrm{HCl}$. In the second step, the minimum concentration of each inhibitory sugar required to inhibit lectin-specific hemagglutination of blood cells by $50 \%$ was determined (Kuku and Eretan, 2004). Two-fold successive dilutions of sugar samples were prepared in PBS (0.2 M initial concentration). Lectins were successively diluted in the microtiter plates until the $12^{\text {th }}$ well on each row. Fifty microlitres of the successively-diluted sugar solutions were added to each well containing the successively-diluted lectins while the control well contained PBS instead of sugar solution. Fifty microlitres of erythrocyte suspension was added to each well, and the hemagglutination titre of the lectin was determined.

\section{Purification of P. soyauxii lectin}

\section{Ammonium sulphate precipitation}

The crude lectin extract of the $P$. soyauxii seeds was subjected to $70 \%$ ammonium sulphate precipitation. The ammonium sulphate equivalent to $70 \%$ precipitation was slowly added to the crude extracts. The mixture was gently stirred to dissolve completely the salt and centrifuged after $24 \mathrm{~h}$ at $3500 \mathrm{rpm}$ for $15 \mathrm{~min}$ to obtain the precipitate. The precipitate was dialysed thoroughly against several changes of PBS to remove the salt and undissolved materials from the dialysates.

\section{Gel-filtration on Sephadex G-100}

The dialysate of ammonium sulphate precipitate of $P$. soyauxii crude lectin extract was applied on Sephadex G-100 column $(2.5 \times 40 \mathrm{~cm})$ previously equilibrated with PBS, $\mathrm{pH}$ 7.2. The protein was eluted with the same buffer at a flow rate of $15 \mathrm{ml} / \mathrm{hr}$ and $5 \mathrm{ml}$ fractions were collected. The fractions were monitored for protein by measuring the absorbance at $280 \mathrm{~nm}$ and assayed for hemagglutinating activity.

\section{Determination of protein concentration}

Protein concentration of the crude extract, dialysate and other fractions were determined by the method of Lowry et al. (1951) using Bovine Serum Albumin (BSA) as standard protein. The absorbance at $280 \mathrm{~nm}$ was also used to monitor protein elution in the chromatographic fractions.

\section{Physicochemical characterization of purified lectin Molecular weight determination}

Native molecular weight of the purified lectin was determined by carried out gel filtration on Sephadex G-100 column $(1.5 \times 100 \mathrm{~cm})$ which had been calibrated with molecular weight markers. Standard protein $(5 \mathrm{ml})$ was applied separately and ran using $10 \mathrm{mM}$ phosphate buffer, $\mathrm{pH} 7.2$ as eluants at a flow rate of $12 \mathrm{ml} / \mathrm{h}$. Fraction of $5 \mathrm{ml}$ were collected and the elution of the protein was monitored at $280 \mathrm{~nm}$. The void volume of the column was determined using Blue dextran which elution's was monitored at 620 $\mathrm{nm}$. The molecular weight markers used were Bovine serum albumin (Mwt 66,000), Ovalbumin (Mwt 45,000), Pepsin (Mwt 35,000), Chymotrypsin (Mwt 25,000); and Lysozyme (Mwt 14,000). $5 \mathrm{mg} / \mathrm{ml}$ of each of the standard protein marker were prepared. The purified $P$. soyauxii seed lectin was also subjected to Sodium Dodecyl SulphatePolyacylamide gel electrophoresis (SDS-PAGE) for subunit molecular weight determination. The procedure described by Weber and Osborn (1975) was used along with lysozyme (Mwt 14,000), trypsin inhibitor (Mwt 20,000), carbonic anhydrase (Mwt 29,000), ovalbumin (Mwt 45,000), bovine serum albumin (Mwt 66,000), galactosidase (Mwt 118,000) and myosin (Mwt 212,000) as standard protein markers.

\section{Effect of temperature on hemagglutinating activity}

The effect of temperature on hemagglutinating activity of $P$. soyauxii seeds lectin and thermal stability of the lectin were done as described by Sampaio et al. (1998). The purified lectin was incubated in a water bath for $1 \mathrm{~h}$ at different temperatures $\left(30{ }^{\circ} \mathrm{C}-100{ }^{\circ} \mathrm{C}\right)$. At each temperature, aliquots of the lectin were taken at $15 \mathrm{~min}$ interval for $60 \mathrm{~min}$, rapidly cooled on ice and assayed for hemagglutinating activity. The hemagglutinating activity of the untreated samples at room temperature represented $100 \%$ hemagglutinating activity.

\section{Effect of $p H$ on hemagglutinating activity}

The effect of $\mathrm{pH}$ on the hemagglutinating activity of the lectin was performed by incubating aliquots of the lectin solutions for $1 \mathrm{~h}$ with buffers of different $\mathrm{pH}$ values ranging from $\mathrm{pH} 3-13$. The buffers used were $0.2 \mathrm{M}$ citrate buffer (pH 3-5), 0.2 M Tris-HCl buffer ( $\mathrm{pH}$ 6-8), and $0.2 \mathrm{M}$ glycine- $\mathrm{NaOH}$ buffer ( $\mathrm{pH}$ 9-13). The hemagglutination 
assays were carried out. Lectin incubated in PBS pH 7.2 was used as the control.

\section{Effect of EDTA and divalent cations on hemagglutinating activity}

The effect of ethylenediaminetetraacetic acid and divalent cations on $P$. soyauxii seeds lectin were carried out as described by Wang et al. (1996). The purified lectins were dialysed against $10 \mathrm{mM}$ EDTA for $24 \mathrm{~h}$ and the hemagglutinating activity of the demetallized lectins was determined. The treated lectins were incubated with $50 \mu \mathrm{l}$ of each of the following cations: $\mathrm{CaCl}_{2}, \mathrm{BaCl}_{2}, \mathrm{MnCl}_{2}$, $\mathrm{SnCl}_{2}$, and $\mathrm{HgCl}_{2}$ at $10 \mathrm{mM}$ for $2 \mathrm{hrs}$ and the hemagglutinating activity of each of the samples were determined.

\section{Antioxidant assays \\ 2, 2-diphenyl-1-picrylhydrazyl (DPPH) radical scavenging assay}

The hydrogen or radical scavenging properties of $P$. soyauxii seeds lectin was determined by the stable radical DPPH (2,2-diphenyl-1-picrylhydrazyl) method as described by Brand-Williams et al. (1995). DPPH $(0.3 \mathrm{mM}, 1 \mathrm{ml})$ was added in methanol to $1 \mathrm{ml}$ of varying concentrations of the lectin/standard (ascorbic acid). The mixture was vortexed and incubated in the dark for $30 \mathrm{~min}$ and the absorbance was measured at $517 \mathrm{~nm}$ against a DPPH negative control containing only $1 \mathrm{ml}$ of the methanol instead of the lectin.

The percentage inhibition of the DPPH scavenging activity was calculated using the equation below:

DPPH \% inhibition $=\left[1-\left(\right.\right.$ Abs sample $_{\text {s }} /$ Abs $\left.\left._{\text {control }}\right)\right] \times 100$

Where:

$\mathrm{Abs}_{\text {sample }}=$ Absorbance of the lectins

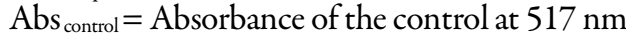

Sample concentration providing 50\% inhibition ( $\mathrm{IC}_{50}$ ) was calculated from the graph by plotting inhibition percentage against sample concentration.

\section{Lipid peroxidation inhibition assay}

The assay of lipid peroxidation activity was carried out according to the thiobarbituric acid reaction method of Kimura et al. (1981) and Hattori et al. (1993) with BHT as standard. Ten percent (10\%) liver homogenate $(0.25 \mathrm{ml})$ was added to $150 \mathrm{mM}$ Tris- $\mathrm{HCl}$ buffer $(\mathrm{pH} 7.2)(0.1 \mathrm{ml})$, $1 \%(\mathrm{w} / \mathrm{v})$ ascorbic acid $(0.05 \mathrm{ml}), 0.07 \mathrm{M} \mathrm{FeSO}_{4}(0.05 \mathrm{ml})$ and varying concentrations of the purified lectin of $P$. soyauxii seeds. The reaction mixtures were incubated at 37 ${ }^{\circ} \mathrm{C}$ for $1 \mathrm{~h}$. After incubation, $0.5 \mathrm{ml}$ of $0.1 \mathrm{~N} \mathrm{HCl}, 0.2 \mathrm{ml}$ of $9.8 \%$ SDS, $0.9 \mathrm{ml}$ of distilled water and $2.0 \mathrm{ml}$ of $0.67 \%$ TBA were added sequentially. The reaction mixtures were heated in boiling water at $100{ }^{\circ} \mathrm{C}$ for $30 \mathrm{~min}$., cooled and $2.0 \mathrm{ml}$ of butan-1-ol was added and later centrifuged at $3000 \mathrm{rpm}$ for $10 \mathrm{~min}$. The supernatant was collected and measured at $532 \mathrm{~nm}$ against reagent blank.

The percentage inhibition was estimated using the expression:

$\%$ Inhibition $=\left(\mathrm{Abs}_{\text {control- }}-\mathrm{Abs}_{\text {test }} / \mathrm{Abs}_{\text {test }}\right) \times 100$

where $\mathrm{Abs}_{\text {control }}=\mathrm{MDA}$ produced by fenton reaction in the absence of extract (control);

$\mathrm{Abs}_{\text {test }}=\mathrm{MDA}$ produced by fenton reaction in the presence of extract.

\section{Metal chelating activity assay}

The metal chelating activity assay was carried out according to the method of Singh and Rajini (2004) with some modifications, using EDTA as standard. Solutions of $2 \mathrm{mM} \mathrm{FeCl}_{2} \cdot 4 \mathrm{H}_{2} \mathrm{O}$ and $5 \mathrm{mM}$ ferrozine were diluted 20 times. Briefly, an aliquot $(1 \mathrm{ml})$ of varying concentrations of purified lectin of $P$. soyauxii seeds was mixed with $1 \mathrm{ml}$ $\mathrm{FeCl}_{2} \cdot 4 \mathrm{H}_{2} \mathrm{O}$. After $5 \mathrm{~min}$ incubation, the reaction was initiated by the addition of ferrozine $(1 \mathrm{ml})$. The mixture was shaken vigorously and after a further $10 \mathrm{~min}$ incubation period, the absorbance of the solution was measured spectrophotometrically at $562 \mathrm{~nm}$. The percentage inhibition of ferrozine- $\mathrm{Fe}^{2+}$ complex formation was calculated by using the formula:

Chelating effect $\%=\left(\mathrm{Abs}_{\text {control }}-\mathrm{Abs}_{\text {sample }} / \mathrm{Abs}\right.$ control $) \times$ 100; where $\mathrm{A}_{\text {control }}=$ absorbance of control sample (the control contains $\mathrm{FeCl}_{2}$ and ferrozine, complex formation molecules);

$\mathrm{A}_{\text {sample }}=$ absorbance of a tested samples.

\section{Results and Discussion}

Pterocarpus soyauxii seeds lectin (PSSL) was purified to homogeneity by combination of ammonium sulphate precipitation and gel filtration on Sephadex G-100. The crude protein extract of petroleum ether-defatted $P$. soyauxii seed powder was subjected to $70 \%$ ammonium sulphate precipitation and the precipitate obtained was thoroughly dialyzed. Dialysate was then layered on the Sephadex G-100 column. Three distinct protein peaks (GFI, GF-II, GF-III) were obtained after the column chromatography. Hemagglutination assay carried out on the pooled fractions of each peak revealed that only the first peak agglutinated erythrocyte (Fig. 1). The same procedure was employed by Galbraith and Goldstein (1970) and e Lacerda et al. (2017). Galbraith and Goldstein (1970) used Sephadex G-200 while e Lacerda et al. (2017) used Sephadex G-100. E Lacerda et al. (2017) obtained three distinct protein peaks and only the first peak exhibited hemagglutinating activity. This is similar to the result of the present study. The methodology established for PSSL purification is efficient because a homogenous molecule was purified by 31 folds with about $13 \%$ recovery. The soluble protein concentration and specific activity of the crude lectin extract were $11.6 \mathrm{mg} / \mathrm{ml}$ and $176.6 \mathrm{HU} / \mathrm{mg}$ proteins respectively and for the purified lectin the value was 1.51 $\mathrm{mg} / \mathrm{ml}$ and $5427.8 \mathrm{HU} / \mathrm{mg}$ proteins respectively (Table 1 ).

Phosphate Buffer Saline ( $\mathrm{pH}$ 7.2) extract of petroleum ether-defatted $P$. soyauxii seeds powder showed relatively high hemagglutinating activity against trypsin-treated and untreated erythrocyte of all human blood group and rabbit (Table 2). Only untreated rat erythrocyte was agglutinated. No blood group specificity was detected because all human blood erythrocyte was agglutinated to a similar degree. There was only slight preference for rabbit erythrocyte. Treatment of erythrocyte with trypsin improved the hemagglutination. Non-blood group specificity of $P$. soyauxii seeds lectin may be due to the presence of multiple binding sites where it can recognize all the determinants of each blood type (Saha et al., 2014). Agglutination of native 
116

Table 1. Summary of purification of lectin from the seeds of Pterocarpus soyauxii

\begin{tabular}{ccccc}
\hline Fraction & ${ }^{\text {a }}$ Total protein $(\mathrm{mg})$ & ${ }^{\text {b}}$ Total activity $(\mathrm{HU})$ & ${ }^{\text {c}}$ Specific activity $(\mathrm{HU} / \mathrm{mg})$ & Purification fold \\
\hline Crude Extract & 11.6 & 2048 & 176.6 & 1 \\
Ammonium Sulphate Dialysate & 4.9 & 2048 & 418.0 & 2.4 \\
Gel Filtration (Sephadex G-100) & 1.51 & 8196 & 5427.8 & 30.7 \\
\hline
\end{tabular}

${ }^{\mathrm{b}}$ Hemagglutinating activity expressed in hemagglutination units which is reciprocal of the highest dilution of the extract exhibiting visible hemagglutination,

${ }^{c}$ Specific activity is calculated as the ratio of Total activity and total protein.

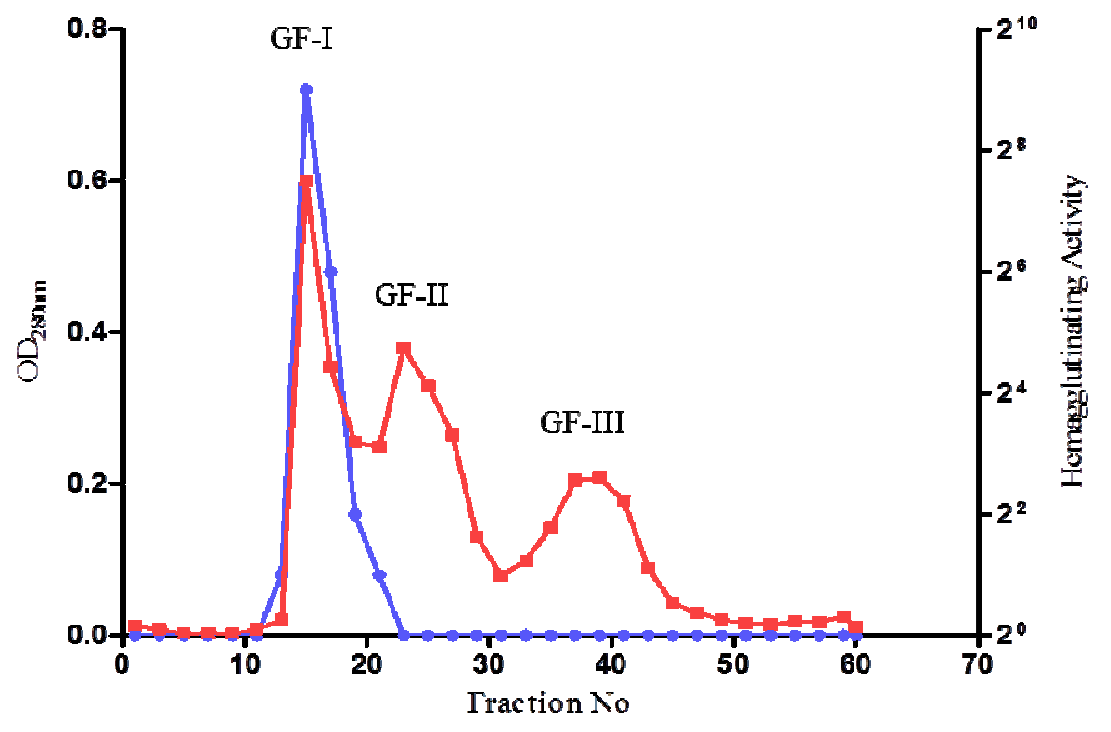

Fig. 1. Purification of PSSL on Sephadex G-100 Column. Approximately $7 \mathrm{ml}$ of dialysate of $70 \%$ ammonium sulphate precipitate was layered on the column $(2.5 \times 40 \mathrm{~cm})$ packed with Sephadex G-100 that was equilibrated with $25 \mathrm{mM}$ Phosphate buffer $\mathrm{pH} 7.2$ containing $100 \mathrm{mM} \mathrm{NaCl}$. The PSSL was eluted with the same buffer at a flow rate of $12 \mathrm{ml} / \mathrm{hr}$ and fractions of 5 $\mathrm{ml}$ were collected, monitor for protein by measuring the absorbance at $280 \mathrm{~nm}$ and hemagglutinating activity of all the fractions

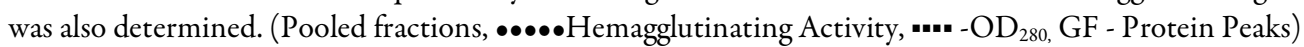

and enzyme-treated rabbit erythrocyte was observed with Dioclea lasiocarpa seed lectin (do Nascimento et al., 2012). The same observation was reported by Silva et al. (2012a), Santiago et al. (2014) and e Lacerda et al. (2015) for lectins isolated from Vatairea guianensis, Canavalia oxyphylla and Mucuna pruriens respectively. Lectin present in the seed of Mucuna sloanei agglutinated both bromelain-treated and untreated human and rabbit erythrocyte (Teixeira-Sá et al., 2009). Bashir et al. (2010) also reported that extent of hemagglutination was the same when erythrocytes of all human blood group were incubated with purified soy-bean (Glycine max) seed lectin. Apuleia leiocarpa seeds lectin also showed hemagglutinating activity toward all blood tested with preference for rabbit erythrocyte (Carvalho et al., 2015). Opposing our findings on hemagglutinating activity, Pereira-Junior et al. (2012) and de Vasconcelos et al. (2015) reported that no hemagglutinating activity was observed for human erythrocytes when incubated with Platymiscium floribundum and Centrolobium microchaete seeds lectin respectively.

Lectin specificity with certain molecules or cells has been described by Gupta et al. (2012) as dependent on both lectin structure and free sugars or sugar residues of polysaccharides, glycoprotein or glycolipids ligands.
Difference in lectin structures and functions may be linked to many different binding site molecular compositions that bind to all kinds of glycosylated ligands. This makes each type of lectin to have high specificity with particular sugars. The sugar specificity of PSSL was investigated by hemagglutination-inhibition assay using different carbohydrates. PSSL hemagglutinating activity was completely inhibited by galactose and galactose-containing sugars. Also, a pentose sugar, arabinose, completely inhibited the lectin activity. Lactose showed better inhibition of PSSL hemagglutinating activity for all human erythrocyte. The minimum inhibitory concentration of sugars that completely inhibited the lectin activity is shown in Table 3. This inhibitory effect on lectin activity gave support to grouping of PSSL as a member of galactosebinding lectin. This is in accordance with sugar specificity reports for majority of leguminous lectins (Konozy et al., 2002 and 2003; Bashir et al., 2010; Sun et al., 2011; Silva et al., 2012a; Kuku et al., 2012; Mishra et al., 2016; Khurtsidze et al., 2017). Some other leguminous lectins that displayed different specificity especially for glucose and mannose or their derivatives have also been reported (do Nascimento $e t$ al., 2012; Silva et al., 2013; Osterne et al., 2014; Santiago et al., 2014; Ng et al., 2015; Pompeu et al., 2015). It was observed that none of the sugars that inhibited PSSL 
hemagglutinating activity using human erythrocyte was able to inhibit the activity against rabbit erythrocyte completely. The presence of carbohydrate moiety on the rabbit erythrocyte surface that have higher affinity for the carbohydrate binding site of the lectin may possibly be preventing the sugars from binding to the lectin thereby stopping their inhibitory effects. There is little or no arabinose-specific lectin in the leguminous lectin family. Arabinose binding lectins are commonly isolated from microorganisms, mushrooms and also marine organisms (Engel et al., 1992; Wang and Ng, 2005). Recently, arabinose was reported to cause partial inhibition of hemagglutinating activity of Apuleia leiocarpa seeds lectin
(Carvalho et al., 2015). Purified lectins from the Dalbergiae tribe have been reported to be composed of diverse isoforms (Calvete et al., 1998; Silva et al., 2012a; Pereira-Junior et al., 2012; de Vasconcelos et al., 2015). Two isolectins were identified in C. microchaete seeds lectin and diverge in lectin chain lengths (de Vasconcelos et al., 2015). There is high possibility of isolectins presence in $P$. soyauxii seeds lectin that diverge in their sugar specificity and likely other properties.

Sodium dodecyl sulphate polyacrylamide gel electrophoresis (SDS-PAGE) of purified PSSL in the presence and absence of reducing agent displayed an electrophoretic profile having a single band corresponding

Table 2. Hemagglutinating activity of PBS extract of $P$. Soyauxii seeds against human and animal erythrocytes

\begin{tabular}{cccc}
\hline \multirow{2}{*}{ Erythrocyte } & & \multicolumn{2}{c}{ Hemagglutinating activity of P. soyauxii } \\
\cline { 2 - 4 } & & Non-trypsinized & Trypsinized \\
\hline \multirow{2}{*}{ Human } & A & 512 & 8196 \\
& $\mathrm{~B}$ & 256 & 16392 \\
Rabbit & $\mathrm{O}$ & 1024 & 8196 \\
Rat & & 16392 & 65568 \\
ND: Not Determined & & 256 & ND
\end{tabular}

Table 3. Inhibition of hemagglutinating activity of PSSL by various carbohydrates in the presence of different erythrocytes

\begin{tabular}{|c|c|c|c|}
\hline Blood & Lactose $(\mathrm{mM})$ & Galactose (mM) & Arabinose $(\mathrm{mM})$ \\
\hline $\mathrm{A}$ & $0.138 \pm 0.057$ & $2.605 \pm 0.520$ & $4.167 \pm 1.042$ \\
\hline B & $0.913 \pm 0.345$ & $6.250 \pm 3.125$ & $8.333 \pm 2.083$ \\
\hline $\mathrm{O}$ & $1.824 \pm 0.689$ & $2.085 \pm 0.520$ & $4.167 \pm 1.042$ \\
\hline
\end{tabular}

Minimum Inhibition Concentration required giving a 50\% inhibition of the agglutination of different erythrocytes. Data are expressed as mean \pm SEM of triplicate determination.

${ }^{*}$ Other sugars used did not completely inhibit the PSSL hemagglutinating activity.

to apparent molecular mass of $35 \mathrm{kDa}$. The native molecular weight of PSSL as determined by gel filtration chromatography was $64.6 \mathrm{kDa}$. The result revealed that PSSL is an homodimeric protein. The result was similar to what was obtained for $P$. coccineus seeds lectin which has 66 $\mathrm{kDa}$ as its native molecular weight and $33 \mathrm{kDa}$ as the subunit mass (Pan and $\mathrm{Ng}, 2015$ ). So also, it is comparable to two species of Mucuna lectins. Mucuna pruriens and $M$. sloanei gave a native molecular weight of $60 \mathrm{kDa}$ and 65.6 $\mathrm{kDa}$ respectively.

Pterocarpus soyauxii seeds lectin (PSSL) was observed to possess high thermal stability, maintaining its full hemagglutinating activity even after incubation up to $60^{\circ} \mathrm{C}$ for $1 \mathrm{~h}$. However, activity was drastically reduced at $70{ }^{\circ} \mathrm{C}$ and completely lost at $80^{\circ} \mathrm{C}$ and higher temperature (Fig. 2a). This implies that the lectins undergo conformational changes under extreme temperatures resulting in the loss of activity. The loss of activity of the lectins with increased temperature is due to destabilisation of sporadic weak interactions of tertiary structure responsible for native conformation of lectin (Singh and Saxena, 2013). These data suggest that PSSL is comparable to other leguminous lectins that exhibited high thermostability. Lectin from $E$. speciosa was also discovered to be stable up until $70{ }^{\circ} \mathrm{C}$, but totally lost its activity at $80{ }^{\circ} \mathrm{C}$ (Konozy et al., 2003). Lectin isolated from $P$. floribundum seeds by Pereira-Junior et al.
(2012) maintained its full lectin activity at $60^{\circ} \mathrm{C}$ for $1 \mathrm{~h}$, but the activity decreases as the temperature increases. Canavalia oxyphylla seed lectin was likewise reported to retain full activity until $60^{\circ} \mathrm{C}$, lost considerable activity at $70{ }^{\circ} \mathrm{C}$ and no activity was observed at $90{ }^{\circ} \mathrm{C}$ (Santiago et al.) 2014). Lectin purified from Phaseolus coccineus (Pan and $\mathrm{Ng}, 2015$ ), Chenopodium quinoa (Pompeu et al., 2015), Apuleia leiocarpa (Carvalho et al., 2015) and Canavalia virosa (Shanmugavel et al., 2016) are all thermostable up to $60{ }^{\circ} \mathrm{C}$ for at least $30 \mathrm{~min}$. High thermostability possessed by these lectins may be advantageous, as stable bioactive substance is more efficient during all phases of their processing and on the other hand this is considered as antinutritional factors that cause many adverse phenomena in animals if ingested (e Lacerda et al., 2017).

Several studies have revealed that stability under highly acidic and basic conditions is a common property of lectins (Pompeu et al., 2015). Lectins are resistant to harsh condition like drastic change in $\mathrm{pH}$. Examination of the effect of $\mathrm{pH}$ on $P$. soyauxii seed lectin showed that the lectin was $\mathrm{pH}$ sensitive. Hemagglutinating activity was optimum at $\mathrm{pH}$ 6-8, relatively insensitive to acidic conditions where it maintained $50 \%$ maximal activity between $\mathrm{pH} 3-5$ but was distinctly affected by basic $\mathrm{pH}$ with the hemagglutinating activity decreasing gradually by $50 \%$ for every unit rise in $\mathrm{pH}$ until pH 13 (Fig. 2b). This result is in agreement with 
118

the reported $\mathrm{pH}$ stability for lectin from Erythrina indica leaves lectin that exhibited pH stability at $\mathrm{pH} 6.0$ - $\mathrm{pH} 8.0$ (Konozy et al., 2002), A. bypogea seed which maintained its maximum activity at $\mathrm{pH} 5.0$ to $\mathrm{pH} 8.0$ (Sun et al., 2011), Dioclea lasiocarpa seeds lectin optimum $\mathrm{pH}$ was between 6.0 and 8.0 (do Nascimento et al., 2012) and $C$. virosa seeds lectin have highest activity at $\mathrm{pH} \quad 4.0-\mathrm{pH} \quad 9.0$ (Shanmugavel et al., 2016).

The hemagglutinating activity of PSSL was not affected after prolong dialysis against EDTA. Also, addition of various divalent ions like $\mathrm{Ca}^{2+}, \mathrm{Mn}^{2+}$ or $\mathrm{Mg}^{2+}$ to the dialyzed lectin did not alter the activity. Though, it has been reported that leguminous lectins require divalent cations like $\mathrm{Ca}^{2+}$, $\mathrm{Mn}^{2+}$ or $\mathrm{Mg}^{2+}$ for their full hemagglutination (EchemendiaBlanco et al., 2009, Sun et al., 2011, do Nascimento et al., 2012, de Vasconcelos et al., 2015, e Lacerda et al, 2017) there are some exception. The current data proposes that, in contrast to other leguminous lectins, PSSL does not need metal ions for it to be fully active or that the metal ions are most likely bound tightly to the inner part of the molecule, shielding it from the EDTA effect. This is comparable to the report of Pereira-Junior et al. (2012), Silva et al. (2012a, b), Santiago et al. (2014), Pompeu et al. (2015) and Khurtsidze et al. (2017).

In determining the antioxidant capability of PSSL, three different in vitro methods for evaluating antioxidant activity were employed. This includes DPPH radical scavenging, metal chelating and lipid peroxidation assays. All methods showed that PSSL possessed antioxidant activity in a dosedependent manner and exhibited an $\mathrm{IC}_{50}$ of $0.14 \pm 1.33$ $\mathrm{mg} / \mathrm{ml}, 3.40 \pm 0.37 \mathrm{mg} / \mathrm{ml}$ and $0.50 \pm 0.08 \mathrm{mg} / \mathrm{ml}$ for these methods respectively (Figs. $3 \mathrm{~A}, \mathrm{~B}$ and $\mathrm{C}$ ). Apart from peptides, obtainable by enzymatic hydrolysis, chemical hydrolysis or bacterial fermentation, that have been established to possess strong antioxidant ability, some proteins from various sources have also been reported to have significant ability to ameliorate the harmful effect of free radicals and reactive oxygen species produced during oxidative stress. Previous investigations, especially on the leguminous seeds, have confirmed that protein from these seeds have antioxidant activity (Carrasco-Castilla et al., 2012; Petchiammal and Hopper, 2014; Pan and Ng, 2015; e Lacerda et al., 2017). Pan and $\mathrm{Ng}$ (2015) reported for the first time the ability of leguminous seed lectin to exert antioxidant activity though the antioxidant activity of lectins from other sources such as Moringa oleifera seeds (Santos et al., 2005), Pleurotus florida (Bera et al., 2011), and endophytic fungi (Sadananda et al., 2014) have been published. Our findings support other studies that reported antioxidant activity for lectins from the Leguminaceae family seeds.
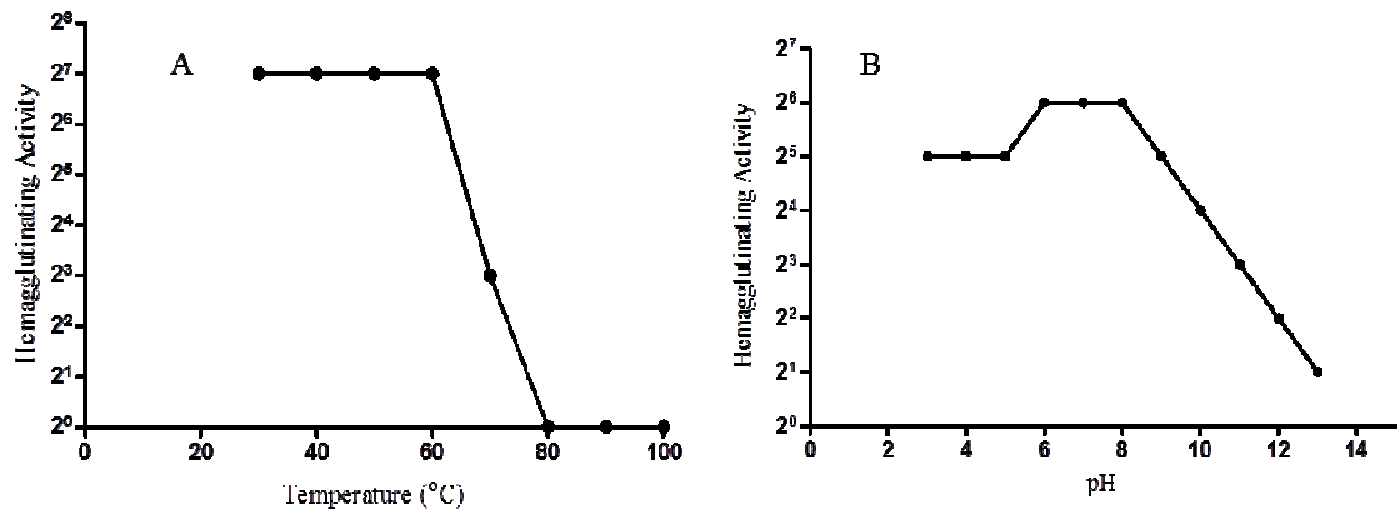

Fig. 2. Effect of temperature and $\mathrm{pH}$ on the hemagglutinating activity of PSSL
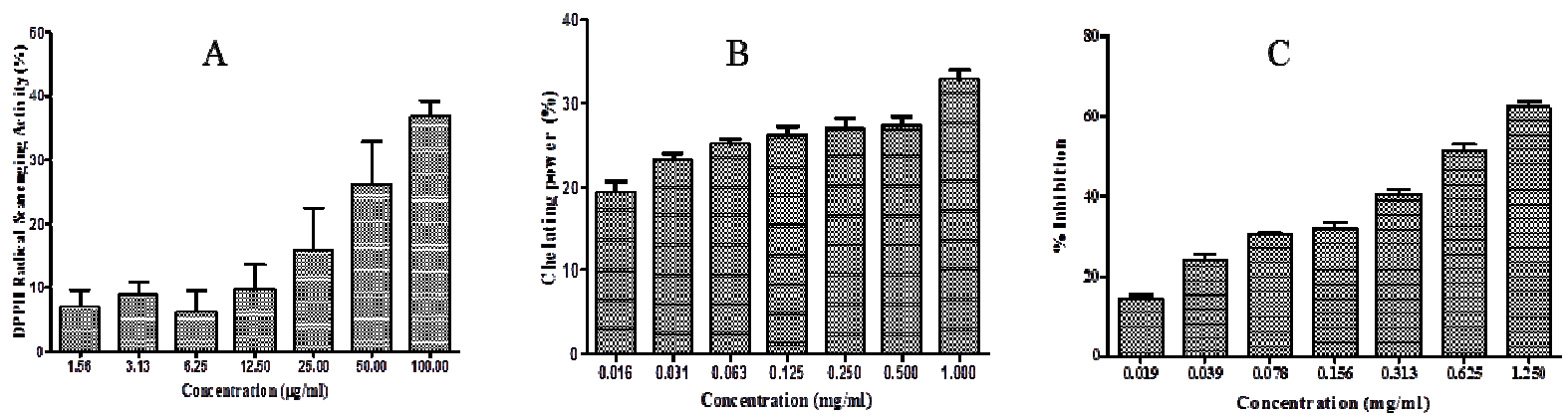

Fig. 3. Antioxidant activity of $P$. soyauxii seeds lectin. [A] DPPH radical scavenging activity [B] Metal chelating activity and [C] Lipid peroxidation inhibition activity. The results are shown as means values \pm SD of three separate experiments 


\section{Conclusions}

The present investigation purified lectin from the seeds of one of the under-utilised plants (Pterocarpus soyauxii) in Nigeria. PSSL lectin agglutinate rabbit and all human blood group erythrocytes, and the hemagglutination were inhibited by galactose, lactose and arabinose. PSSL lectin is not a metal dependent lectin, maximum hemagglutinating activity was observed up to $60^{\circ} \mathrm{C}$ and around $\mathrm{pH}$ values of 6-8. It possessed antioxidant activity which was detected using three different methods. Future studies are required to determine other properties and also biological activities of this lectin. The mechanism of action of its antioxidative prowess will also need future studies.

\section{References}

Almeida AC, Osterne VJS, Santiago MQ, Pinto-Junior VR, Silva-FilhoJS ... Cavada BS (2016). Structural analysis of Centrolobium tomentosum seed lectin with inflammatory activity. Archives of Biochemistry and Biophysics 596:73-83.

Anitha N, Sathisha GJ (2017). Evaluation of antibacterial and antioxidant activities of partially purified lectin from tubers of Xanthosoma violaceum. European Journal of Biomedical and Pharmaceutical Sciences 4(11):420-425.

Bashir H, Khan T, Masood A, Hamid (2010). Isolation, purification and characterization of a lectin from a local Kashmiri variety of soybean (Glycinemax). Asian Journal of Biochemistry 5(3):145-153.

Benevides RG, Ganne G, Simoes RC, Schubert V, Niemietz M, ... Imberty A (2012). A lectin from Platypodium elegans with unusual specificity and affinity for asymmetric complex N-glycans. Journal of Biological Chemistry287(31):26352-26363.

Bera AK, Rana T, Bhattacharya D, Das S, Pan D, Das SK (2011). Sodium arsenite-induced alteration in hepatocyte function of rat with special emphasis on superoxide dismutase expression pathway and its prevention by mushroom lectin. Basic and Clinical Pharmacology \&Toxicology 109(4):240-244.

Bouwman LH, Roep BO, Roos A (2006). Mannose-binding lectin: clinical implications for infection, transplantation and autoimmunity. Human Immunology 67(4-5):247-256.

Brand-Williams W, Cuvelier ME, Besert CLWT (1995). Use of a free radical method to evaluate antioxidant activity. LWT-Food Science and Technology 28(1):25-30.

Calvete JJ, Santos CF, Mann K, Grangerio TB, Nimtz M, ... Cavada BS (1998). Amino acid sequence, gycan structure and proteolytic processing of the lectin of Vatairea macrocarpa seeds. FEBS Letter 425(2):286-292

Carrasco-Castilla J, Hernandez-Álvarez AJ, Jiménez-Martínez C, JacintoHernández C, Alaiz M, ... Dávilla-Ortiz G (2012). Antioxidant and metal chelating activities of Phaseolus vulgaris L. var. Jamapa protein isolates, phaseolin and lectin hydrolysates. Food Chemistry 131(4):1157-1164.

Carvalho AS, da Silva MV, Gomes FS, Paiva PM, Malafaia CB, ... Correia MT (2015). Purification, characterization and antibacterial potential of a lectin isolated from Apuleia leiocarpa seeds. International Journal of Biological Macromolecules 75:402-408.

Coffey DG, Uebersax MA, Hosfield GL, Bennick MR (1993). Thermal extrusion and alkali processing of dry beans (Phaseolus vulgaris). Journal of Food Processing and Preservatives 16(6):421-431.

Dan X, Liu W, Ng TB (2016). Development and applications of lectins as biological tools in biomedical research. Medicinal Research Reviews 36(2):221-247.

de Vasconcelos MA, Alves AC, Carneiro RF, Dias AHS, Martins FWV, .... Cavada BS (2015). Purification and primary structure of a novel mannose-specific lectin from Centrolobium microchaete Mart seeds. International Journal of Biological Macromolecules 81:600-607.

do Nascimento ASF, Gondim ACS, Cajazeiras JB, Correia JLA, Pires AF, .... Cavada BS (2012). Purification and partial characterization of a novel lectin from Dioclea lasiocarpa Mart seeds with vasodilator effects. Journal of Molecular Recognition 25(12):657-664.

Echemendia-Blanco D, Driessche EV, Ncube I, Read JS, Beeckmans S (2009). Stability, subunit interactions and carbohydrate-binding of the seed lectin from Pterocarpus angolensis.Protein and Peptide Letters 16(9):1120-1134.

e Lacerda RR, Moreira IC, de-Lacerda ACS, Cabral NL, Lucetti, DL, ... Santi-Gadelha T (2015). Lectin isolated from Brazilian seeds of velvet beans (Mucuna pruriens (L) DC.) presents analgesic, anti-inflamatory and antihemolytic action. Journal of Medicinal Plant Research 9(8):231-242.

eLacerda RR, doNascimentoES, de Lacerda JTJG, daSilva Pinto L, RizziC, ...De Almeida Gadelha TS (2017). Lectin from seeds of a Brazilian lima bean variety (Phaseolus lunatus L. Var. cascavel) presents antioxidant, antitumor and gastroprotective activities. International Journal of Biological Macromolecules 95:1072-1081.

Engel M, Bachmann M, Schröder HC, Rinkevich B, Kljajic Z, ... Muller WEG (1992). A novel galactose-and arabinose-specific lectin from the sponge Pellina semitubulosa: isolation, characterization and immunological properties. Biochimie 74(6):527-537.

Galbraith W, Goldstein IJ (1970). Phytohemagglutinins: a new class of metalloprotein: Isolation, purification and some properties of the lectin from Phaseoluslunatus. FEBSLetter 9(4):197-201.

Gill LS (1992). Ethnomedical uses of plants in Nigeria. Uniben Press, University of Benin pp 200-201.

Gupta GS (2012). Animal lectins: forms, function and clinical application, Springer, Vienna pp 1108.

Hamid R, Masood A, Wani IH, Rafiq S (2013). Lectins: Proteins with diverse applications. Journal of Applied Pharmaceutical Science 3(4):S93-S103.

Hattori M, Yang XW, Miyashiro H, Namba T (1993). Inhibitory effects of monomeric and dimeric phenylpropanoids from mace on lipid peroxidation in vivo and in vitro. Phytotherapy Research 7(6):395-401.

Hendrickson OD, Zherdev AV (2018). Analytical application of lectin. Critical Reviews in Analytical Chemistry 48(4):279-292.

Huskens D, Schols D (2012). Algal lectins as potential HIV microbicide candidates. Marine Drugs 10(7):1476-1497.

Inbar J, Chet I (1997). Lectins and biocontrol. Critical Reviews in Biotechnology 17(1):1-20. 
120

Joubert FJ, Sharon N, Merrifield EH (1986). Purification and properties of a lectin from Lonchocarpus capassa (apple leaf) seed. Phytochemistry 25(2):323-327.

Khurtsidze E, Kutchava T, Pomikalova N, Gaidamashvili M (2017). Galactose-binding lectin from mulberry (Morus alba L) seeds with growth hormone-like activity. Annals of Agrarian Science 15(1):26-30.

Kimura Y, Kubo M, Tani T, Arichi S, Okuda H (1981). Studies on Scutellariae radix. IV.Effects on lipid peroxidation in rat liver. Chemical and Pharmaceutical Bulletin 29(9):2610-2617.

Konozy EH, Mulay R, Faca V, Ward RJ, Greene LJ, ... Bhide SV (2002). Purification, some properties of a D-galactose-binding leaf lectin from Erythrina indica and further characterization of seed lectin. Biochimie 84(10):1035-1043.

Konozy EH, Bernardes ES, Rosa C, Faca V, Greene LJ, Ward RJ (2003). Isolation, purification, and physicochemical characterization of a Dgalactose-binding lectin from seeds of Erythrina speciosa. Archives of Biochemistry and Biophysics 410(2):222-229.

Kuku A, Eretan OB (2004). Purification and partial characterization of a lectin from the fresh leaves of Kalanchoe crenata (Andr.) Haw.Journal of Biochemistry and Molecular Biology 37(2):229-233.

Kuku A, Odekanyin OO, Okonji RE (2012). Physicochemical properties of a lactose specific lectin from the seeds of Erythrina senegalensis DC.Ife Journal of Science 14(1):143-153.

Kumar KK, Chandra KLP, Sumanthi J, Reddy GS, Shekar PC, Reddy B (2012). Biological roles of lectins: A review. Journal of Orofacial Sciences $4(1): 20-25$.

Lagarda-Diaz I, Guzman-Partida AM, Vazquez-Moreno L (2017). Legume lectins: protein with diverse applications. International Journal of Molecular Sciences 18(6):1242.

Lam SK, Ng TB (2011). Lectins: production and practical applications. Applied Microbiology andBiotechnology 89(1):45-55.

Lowry OH, Rosebrough NJ, Farr AL, Randall R (1951). Protein measurement using Folin phenol reagent.Journal of Biological Chemistry 193(1):265-275.

Mishra RP, Ganaie AA, Allaie AH (2016). Isolation and purification of a Galactose specific lectin from seeds of Baubinia variegata and evaluation of its antimicrobial potential. International Journal of Pharmaceutical Science and Research 7(2):804815.

Ng TB, Chan YS, Ng CCW, Wong JH (2015). Purification and characterization of a lectin from green split peas (Pisum sativum). Applied Biochemistry and Biotechnology 177(6):13741385.

Occena IV, Mojica EE, Merca FE (2007). Isolation and partial characterization of a lectin from the seeds of Artocarpus camansi Blanco. Asian Journal of Plant Sciences 6(5):757-764.

Odekanyin OO, Kuku A (2014). Characterization of galactose-specific lectin from the skin mucus of African catfish Clarias gariepinus. Scientific Research and Essays 9(20):869-879.

Olodude SO, Odekanyin OO, Fatokun AB (2017). Evaluation of antioxidant and carbohydrate hydrolysing enzymes inhibitory activities of Trilepisium madagascariense Ficalho seeds hemagglutinin. IOSR Journal of Pharmacy and Biological Sciences 12(6):29-41.

Osterne VJ, Santiago MQ, Pinto-Junior VR, Cajazeiras JB, Correia JL ....
Cavada BS (2014). Purification, partial characterization and $\mathrm{CNBr}$ Sepharose immobilization of a vasorelaxant glucose/mannose lectin from Canavalia virosa seeds. Applied Biochemistry and Biotechnology 172(7):3342-3353.

Osuagwu GGE, Akomas CB (2013). Antimicrobial activity of the leaves of three species of Nigerian Pterocarpus (Jacq.). International Journal of Medicinal and Aromatic Plants 3(2):178-183.

Pan WL, Ng TB (2015). A dimeric Phaseolus coccineus lectin with antioxidative, anti-proliferative and cytokine-inducing activities. International Journal of Biological Macromolecules 81:960-966.

Pattanapanyasat K, Noulsri E, Lerdwana S, Sukapirom K, Onlamoon N, Tassaneetrithep B (2010). The use of glutaraldehyde-fixed chicken red blood cells as counting beads for performing affordable single-platform $\mathrm{CD}^{4+}$ T-lymphocyte count in HIV-1-infected patients. Journal of Acquired Immune Deficiency Syndromes 53(1):47-54.

Pereira-Junior FN, Silva HC, Freitas BT, Rocha BAM, Nascimento KS, ... Cavada BS (2012). Purification and characterization of a mannose/Nacetyl-D-glucosamine-specific lectin from the seeds of Platymiscium floribundum Vogel.Journal of Molecular Recognition 25(8):443-449.

Petchiammal C, Hopper WAHEETA (2014). Antioxidant activity of proteins from fifteen varieties of legume seeds commonly consumed in India. International Journal of Pharmacy and Pharmaceutical Sciences 6(1-2):476-479.

Pompeu DG, Mattioli MA, Ribeiro RIMA, Goncalves DB, de Magalhaes JT ... Granjeiro PA (2015). Purification, partial characterization and antimicrobial activity of lectin from Chenopodium quinoa seeds. Food Science and Technology (Campinas) 35(4):696-703.

Sadananda TS, Govindappa M, Ramachandra YL (2014). In vitro antioxidant activity of lectin from different endophytic fungi of $V$ iscum album L. British Journal of Pharmaceutical Research 4(5):626.

Saha RK, Acharya S, Jamiruddin M, Roy P, Islam MMS, ... Shovon, SSH (2014). Antimicrobial effects of a crude plant lectin isolated from the stem of Tinospora tomentosa. Journal of Phytopharmacology 3:4451.

Saliu JA, Elekofehinti OO, Komolafe K, Oboh G (2012). Effects of some green leafy vegetables on the haematological parameters of diabetic rats. Journal of Natural Product and Plant Resources 2(4):482-485.

Sampaio AH, Rogers DJ, Barwell CJ (1998). A galactose-specific lectin from the red marine alga Ptilota filicina. Phytochemistry 48(5):765-769.

Santiago MQ, Leitão CC, Pereira-Junior FN, Pinto-Junior VR, Osterne JS, ... Cavada BS (2014). Purification, characterization and partial sequence of a pro-inflammatory lectin from seeds of Canavalia oxyphylla Standl. \&LOWilliams. Journal of Molecular Recognition 27(3):117-123.

Santos AFS, Argolo ACC, Coelho LCBB, Paiva PM (2005). Detection of water-soluble lectin and antioxidant component from Moringa oleifera seeds. Water Research 39(6):975-980.

Santos AFS, da Silva MDC, Napoleão TH, Paiva PMG, Correia MTS, Coelho LCBB (2014). Lectins: function, structure, biological properties and potential application. Current Topics in Peptide and Protein Research 15:41-62.

Shanmugavel S, Velayutham V, Kamalanathan T, Periasamy M, Munusamy A, Sundaram J (2016). Isolation and analysis of mannose/trehalose/maltose specific lectin from jack bean with 
antibruchid activity. International Journal of Biological Macromolecules 91:1-14.

Sharon N, Lis H (2004). History of Lectins: From hemagglutinins to biological recognition molecules. Glycobiology 14(1):53R-62R

Silva HC, Nagano CS, Souza LA, Nascimento KS, Isídro R, ... Damasceno LEA (2012a). Purification and primary structure determination of a galactose-specific lectin from Vatairea guianensis Aublet seeds that exhibits vasorelaxant effect. Process Biochemistry 47(12):2347-2355.

Silva MC, Santana LA, Mentele R, Ferreira RS,de Miranda A, ... Oliva MLV (2012b). Purification, primary structure and potential functions of a novel lectin from Baubinia forficata seeds. Process Biochemistry 47(7):1049-1059.

Silva HC, Bari AU, Rocha BAM, Nascimento KS, Ponte EL, Pires AF, ... Nagano CS (2013). Purification and primary structure of a mannose/glucose-binding lectin from Parkia biglobosa Jacq. Seeds with antinociceptive and anti-inflammatory properties. Journal of Molecular Recognition 26(10):470-478.

Singh RS, Tiwary AK, Kennedy JF (1999). Lectins: Sources, activities and applications. Critical Reviews in Biotechnology 19(2):145-178.

Singh N, Rajini PS (2004). Free radical scavenging activity of an aqueous extract of potato peel. Food Chemistry 85(4):611-616.

Singh AP, Saxena KD (2013). Biological Activity of Purified Momardica Charantia Lectin. Chemical Science Transactions 2:258-262.

Sun J, Yang QL, Bi J, Zhang CS, Yu LN, Zhu F (2011). Purification and identification of a natural lectin from the seed of peanut Arachis hypogea. The Open Materials Science Journal 5:78-82.
Tchamadeu MC, Dzeufiet PDD, Nana P,Nouga CK, Tsofack FN,... Tack I (2011). Acute and sub-chronic oral toxicity studies of an aqueous stem bark extract of Pterocarpus soyauxii Taub (Papilionaceae) in rodents. Journal of Ethnopharmacology 133(2):329-335.

Teixeira-Sá DM, Reicher F, Braga RC, Beltramini LM, deAzavedo MR (2009). Isolation of a lectin and a galactoxyloglucan from Mucuna sloanei seeds. Phytochemistry70(17-18):1965-1972.

Uzodimma D (2013). Medico-ethnobotanical inventory of Ogii, Okigwe Imo State, South Eastern Nigeria-I. Global Advanced Research Journal of Medicinal Plants (GARJMP) 2:030-044.

Wang HX, Liu WK, Ng TB, Ooi VEC, Chang ST (1996). The immunomodulatory and antitumour activities of lectins from the mushroom Tricholoma mongolicum. Immunopharmacology31(23):205-211.

Wang $\mathrm{H}, \mathrm{Ng} \mathrm{TB}$ (2005). First report of an arabinose specific fungal lectin. Biochemical Biophysical Research Communication 337(2):621-625.

Weber K, Osborn M (1975). Protein and sodium dodecyl sulphate: molecular weight determination on polyacrylamide gels and related procedures. Chapter 3 In “The Protein". Edited by Neurath H and Hill RL. Academic press, New York, Vol 1,pp 179-223.

Yau T, Dan X, NgCC, NgTB (2015). Lectins with potential for anticancer therapy. Molecules 20(3):3791-3810. 